\title{
Economic viability of a food hub business: Assessment of annual operational expenses and revenues
}

\author{
Olya Rysin ${ }^{a}$ and Rebecca Dunning $b$ \\ North Carolina State University
}

Submitted December 14, 2015 / Revised February 16, March 9, and March 14, 2016 /

Accepted March 14, 2016 / Published online August 4, 2016

Citation: Rysin, O., \& Dunning, R. (2016). Economic viability of a food hub business: Assessment

of annual operational expenses and revenues. Journal of Agriculture, Food Systems, and Community

Development, 6(4), 7-20. http://dx.doi.org/10.5304/jafscd.2016.064.002

Copyright (C) 2016 by New Leaf Associates, Inc.

\begin{abstract}
Food hubs-aggregation and distribution entities with social missions that include localization of food production and distribution systems - are receiving increasing attention from the public and foundation sectors as a means of catalyzing economic development in rural and peri-urban areas. Funding proposals for food hubs are often couched in terms of initial start-up capital, with all involved parties expecting the hub to become selfsufficient of outside funding within 5 years. In this paper we comprehensively assess the annual operational revenues and expenses of four food hubs operating in North Carolina in 2014, and use these as a basis to estimate the model annual operating budget for a food hub business serving as an intermediary between small and midscale

\footnotetext{
a * Corresponding author: Olya Rysin, Center for Integrated Pest Management, North Carolina State University; Raleigh, North Carolina, USA; olya rysin@ncsu.edu

b Rebecca Dunning, Center for Environmental Farming Systems, North Carolina State University; Raleigh, North Carolina, USA.
}

farmers and grocery stores, restaurants, and institutional food service. This analysis focuses on annual operational expenses and the ability of established food hubs to function independently of outside funding. The analysis of business operations also includes sensitivity analysis to estimate required revenues based on variation in operational expenses and the mark-up fees that hubs charge their growers. We find that the average losses, excluding monetary donations, sustained in 2014 by the hubs were $\$ 86,2041$ on average produce sales of $\$ 162,668$. Assuming a $20 \%$ average mark-up fee and based on the model budget of annual operating costs, a food hub operation requires total annual sales of approximately $\$ 800,000$ to cover its operating costs.

\section{Keywords}

Alternative Food Distribution Channels; Local Food Systems; Sensitivity Analysis; Food Hub; Food System Infrastructure

${ }^{1}$ All mentions of currency are in U.S. dollars. 


\section{Introduction}

Localizing food systems to connect local production with local consumption continues to spark interest across the agricultural, planning and economic development practitioner communities (Blay-Palmer, Landman, Knezevic, \& Hayhurst, 2013; Cleveland, Müller, Tranovich, Mazaroli, \& Hinson, 2014; Pothukuchi, 2015). Shorter supply chains between production and consumption can support local agriculture and affiliated businesses both upstream in the chain to local input suppliers and downstream to local value-added operations. Localization can improve the economic viability of small and midscale growers and catalyze agri-food enterprise diversification (Gillespie, Hilchey, Hinrichs, \& Feenstra, 2007; Hinrichs, Gillespie, \& Feenstra, 2004; King et al., 2010), and in some cases decrease total system costs, including prices paid by consumers and food miles traveled (Atallah, Gómez, \& Björkman, 2014).

Over the past decade, farmers markets have been the most common form of publicly funded local food infrastructure in the United States, with the U.S. Department of Agriculture's Agricultural Marketing Service (USDA AMS) awarding \$59.2 million since 2009 to local governments, nonprofits, and other organizations through its Farmers Market Promotion Program (Wood, 2015). Between 2000 and 2014, the number of markets in the USDA's Farmers Market Directory tripled to over 8,000 nationwide (USDA AMS, n.d.-a). After a period of rapid expansion, however, this sector may be nearing saturation, with the growth in this organizational form slowing to an increase of just 1.5\% between 2013 and 2014 (Low et al., 2015).

In response to this and coupled with the continued popularity of local foods, food hubs have emerged as an alternative form of publicly funded local food infrastructure. Food hubs, aggregation and distribution entities with a social mission to localize food distribution systems, address the need for infrastructure capable of linking the small and midscale growers that characterize local food systems to larger, mainstream markets such as grocery stores, restaurants, and institutional food service (Low \& Vogel, 2011; Martinez et al., 2010). As of late 2015, the USDA's directory of food hubs stood at 157 (USDA AMS. n.d.-b), with food hub development actively supported by the USDA's Know Your Farmer, Know Your Food initiative and affiliated federal grant programs (USDA, n.d.). Despite the continued growth in funding on national, regional, and local levels for food hub creation and operational support, funders lack detailed estimates of the operating costs and returns required to support food hubs over time. Such information is needed to plan and evaluate hubs' potential to generate sufficient revenues to be self-sustainable in the long run. The national Counting Values: Food Hub Financial Benchmarking Study (Farm Credit East, Wallace Center at Winrock International, Morse Marketing Connections, \& Farm Credit Council, 2015) found that the average profit margin for the U.S. food hub sector, based on survey results from 48 hubs in 2013, was negative $2 \%$, indicating that most food hubs require ongoing public support to continue operations.

The objective of the current study was to make a detailed assessment of the annual operational revenues and expenses of four food hubs operating in North Carolina in 2014 and to use these as a basis for estimating the required annual operating budget and annual sales revenues that would allow a food hub to function independently of external funding. This information will benefit individuals and organizations in the planning stages for a new food hub, as well as aid federal, state, and local governments and various other organizations and institutions in assessing the ability of a hub to operate as a financially self-sustained business.

We begin with background information on food hubs as an organizational form and a review of the available research on social and economic impacts attributed to local food infrastructure, including food hubs, as well as factors related to their economic viability. We then discuss the methodology used for data collection and subsequent construction of a model annual food hub operating budget. We conclude with a summary and discussion of our findings.

\section{Background}

A food hub is defined as "a business or organization that actively manages the aggregation, 
distribution and marketing of source-identified food products primarily from local and regional producers to strengthen [those producers'] ability to satisfy wholesale, retail, and institutional demand" (Barham, Tropp, Enterline, Farbman, Fisk, \& Kiraly, 2012, p. 4). With demand for locally sourced food growing among conventional grocery retailers and restaurants eager to use the "local" attribute to gain a competitive edge over rivals, food hubs have emerged as intermediary organizations to bridge the scale differences between small and midsize growers and the volume and product standardization requirements of grocery stores and food service establishments (restaurants and institutions such as universities or hospitals). Some food hubs focus on direct-to-consumer sales channels, such as a set of farms aggregating product for sale to consumers through a community supported agriculture (CSA)-style box program, or combine direct-to-consumer sales with sales to wholesale markets (see Matson, Thayer, and Shaw [2015] for a description of food hub operational types). The food hubs considered in the present study supply grocery stores, restaurants, and institutions.

As aggregators and distributors of agricultural products, most often fresh produce, hubs operate in much the same way as traditional wholesale and distribution businesses, typically taking on the following supply chain functions: aggregation of product delivered by farmers; marketing of this product to various channels; quality control, grading, and packing to buyer specifications; delivery of product to buyers; and associated administrative and accounting functions (Barham et al., 2012). Unlike for-profit private food distributors, however, food hubs are assumed to play an active role in supporting the development of local and regional food systems and to exhibit missiondriven values. They also often receive funding support for both investment and subsequent operational costs from various sources (Barham et al., 2012; Fischer, Pirog, \& Hamm, 2015). Thus food hubs differ from traditional wholesale and distribution businesses because the former are social enterprises which include in their mission social objectives such as conserving farmland, supporting local farmers, and improving lowincome community access to local fresh foods
(Cantrell \& Heuer, 2014; Fisher et al., 2015). Research findings largely based on qualitative single- and multisite case studies suggest that food hubs and other means of food system localization have the potential to generate multiple short- and long-term social and economic benefits. Hubsubsidized services facilitate business connections from agricultural producers into supply chains that they otherwise could not access due to the packing, volume, and distributional requirements, and other specifications associated with larger players (Day-

Farnsworth \& Morales, 2011). Food hubs, farmers markets, and other infrastructure supporting the development of local and regional food systems may have an impact on slowing farm and farmland loss (Marticorena, 2015) and thus maintaining the farmland asset base and human capital skills in agricultural production. Evidence from the 2012 Census of Agriculture and other data sources also suggests that shorter supply chains between growers and consumers enhance the economic viability of growers (Low et al., 2015) and have positive regional economic impacts (O’Hara \& Pirog, 2013).

In addition to the direct positive impact on farm viability and related benefits, food localization also may offer more broad-based and long-term socioeconomic benefits. Like farmers markets, food hubs may serve as sites for entrepreneurial development and catalyze other locally owned small businesses (Hinrichs, Gillespie, \& Feenstra, 2004; McFadden \& Marshall, 2014). Similar to farmers markets, the existence of food hubs in a community can enhance awareness of local agricultural production and physically connect fresh food sources to low-access points in an area (LeBlanc, Conner, McRae, \& Darby, 2014). Greater consumer awareness of how food is produced and distributed and the resulting effects on individuals and communities may lead to more sustainable farming practices, greater diversity in farm ownership, and more resilient food systems responsive to local needs (Connelly, Markey, \& Roseland, 2011; Dunning, Bloom, \& Creamer, 2015; Hodbod \& Eakin, 2015; Lutz \& Schachinger, 2013). While qualitative research suggests that multiple benefits accrue to communities with local food infrastructure, including food hubs, the 
quantitative evidence of the impact of food hubs (and other local and regional food system infrastructure) on economic development outcomes is much more limited, largely due to the time and cost involved for data collection and analysis (O'Hara \& Pirog, 2013). The available research on food hub economic impact examined expenditures from a single hub in New York state, finding a multiplier effect of $\$ 1.63$ for each $\$ 1$ in hub revenue (Schmit, Jablonski, \& Kay, 2015).

The Michigan State University Center for Regional Food Systems and the Wallace Center at Winrock International surveyed hubs in 2011 and 2013 to better understand factors related to food hub economic viability. The 2013 report indicated that of 78 self-identified food hub businesses, half generated sufficient sales to cover their operational expenses (Fischer, 2014; Fischer, Hamm, Pirog, Fisk, Farbman, \& Kiraly, 2013; Fischer et al., 2015). Summary reports of both the 2011 and 2013 surveys concluded that financially viable hubs were those that generated over $\$ 600,000$ in annual revenues. In the 2014 survey, the majority of hubs generated annual sales of less than $\$ 500,000$ and had five or fewer employees. Regression analysis of the information on the 78 hubs (of a total of 162 responding) that provided sufficient economic data for analysis found that the most important predictors of financial viability were the absolute amount of annual gross revenue and an expenditure profile characterized by relatively lower percentages of operating costs in transportation expenses and employee salary and benefits (Fischer et al., 2015). Geographic location, length of operation, and legal structure were not found to be predictive of economic viability. Matson and Barham (2015) compare break-evens and viability of wholesale, directto-consumer, and hybrid models of food hub operations. They estimate that sales of approximately $\$ 1.2$ million are required to sustain wholesale and hybrid models, while sales of only approximately $\$ 300,000$ are needed to sustain the direct-to-consumer model.

More information is available on the economic viability of individual food hub businesses in the form of single-site case studies or single-site feasibility studies (e.g., Barham et al., 2012; Dion, Shugart, Hale, \& Saavedra, 2013; Gunter,
Thilmany, \& Sullins, 2012; Horst, Ringstrom, Tyman, Ward, Werner, \& Born, 2011; Jablonski, Perez-Burgos, \& Gómez, 2011; Lindsey \& Slama, 2012; Purcell, 2014; Smithson Mills, Inc., 2009, 2012; Van Dis, 2012). Such single-case studies, especially if conducted as ex ante feasibility studies, may be reflecting very specific circumstances of a single hub and/or may not give an accurate assessment of future expenses and revenues.

The current study complements existing research and survey results through an examination of the finances of four food hubs that had been in operation for 2 or more years. Our unique focus is on the ability of an established food hub to operate independently of external funding. In the following sections we present an economic comparison of operating expenses and returns of four food hubs and generate a composite model operating budget. Using the profit and loss statements for these hubs and sensitivity analysis for volume and hub service fees and/or mark-ups to growers, we provide informed estimates of what communities can expect when making the investment in a food hub.

\section{Methods}

In 2015, we visited four North Carolina food hubs that were operating in 2014. These food hubs had similar missions focused on the socioeconomic benefits of food hub localization, but had different histories and business management and organizational structures. While all hubs sought to provide services to small and midscale produce growers (typically growers of diversified vegetable crops on less than 30 acres [12 hectares]), they targeted different market channels, with two focusing on direct-to-restaurant sales and the other two focusing on sales to a grocery distributor. During these visits, we collected detailed information about the hubs' management and financial records for 2014. The goal was to explore the annual costs required to operate a produce food hub business serving as an intermediary between small and midscale growers and grocery and institutional buyers, and the corresponding annual revenues from produce sales needed to recover these costs. Based on information we collected as well as conversations with hub managers, we created a model operating budget for a wholesale food hub, and conducted 
additional sensitivity analysis to understand changes in facility breakeven points in response to changes in facility throughput and service fees and/or mark-ups to growers.

\section{Food Hub Descriptions}

Hub $\mathrm{A}^{2}$ is one component of a university-based nonprofit organization founded in 2006. The hub is based in the North Carolina eastern coastal plain in a county characterized by an average farm size of 172 acres (70 hectares) and dominated by livestock, dairy, and poultry operations; row crops; and smaller acreages of tobacco and specialty crops, including berries and peaches (USDA NASS, 2014). The umbrella nonprofit began as an economic and community development initiative to create a fully integrated local food system, with the hub component serving small farmers within an approximate 60 -mile $(96-\mathrm{km})$ radius in selling to markets that they were unable to access, including restaurants, grocers, schools, and hospitals. Initial financing for the hub structure and staff was received through grants and foundations, and the hub continues to rely on these for operational expenses.

In 2014 the farmer base of the hub included midscale organic farms of 20 to 100 acres (8 to 40 hectares), small and midscale conventional farms on 3 to 50 acres ( 1 to 20 hectares), and new farmers who had purchased or were leasing land to begin farming of 3 to 15 acres (1 to 6 hectares). About $80 \%$ of the farmers who sold through the hub in 2014 held either full-time jobs or had retirement income.

Occasionally farmers delivered products to the hub where they could be held overnight in a small cold-storage area. More frequently, products were delivered in the early morning and immediately sorted by hub staff into orders for two dozen restaurants and two grocery stores in a nearby urban area. In 2014, the hub operated year-round, and a rental truck and driver delivered products once per week. The primary products were produce items, with additional small sales $(<5 \%$ of revenue) of local meats, eggs, and goat cheese. The

2 One participating hub requested to not be named, so for consistency we do not identify any of them. hub sold about $50 \%$ of its product directly to restaurants and the other $50 \%$ directly to grocery stores.

Hub B, located in the North Carolina Piedmont, was founded in 2010 to assist small and midscale farmers in accessing nearby markets in the state's Triad region (Winston-Salem, Greensboro, and High Point metro areas). The average farm size in the area is 91 acres ( 37 hectares). Agricultural production is heavily dominated by livestock and tobacco production, with some corn for silage as well as specialty crops (USDA NASS, 2014). While Hub B suspended its operations at the end of 2014, its 2014 income and expenses were typical of prior years. Most of the farmers selling through Hub B had previously relied upon tobacco as either their primary or secondary income and looked to specialty crops as the only replacement that could generate sufficient income on small acreages (typically $<15$ acres [ 6 hectares]) to continue farming. Like Hub A, the primary goal of the hub was to maintain farming as an economically viable option in the area by connecting local farmers to retail, wholesale, and institutional market channels.

Hub B was owned by a county economic development foundation that subsidized its startup and continued to subsidize operating expenses until its closure. The facility also received grant and foundation funding at start-up and in subsequent years. Hub B aggregated and distributed produce from growers within an approximate 40-mile (64$\mathrm{km})$ radius and sold about $10 \%$ of its product direct to grocery stores and $90 \%$ through a grocery distributor located 110 miles $(180 \mathrm{~km})$ from the hub. The facility's services included grading, packing, storage, and refrigeration, and the facility was certified in USDA Good Handling Practices. Deliveries were done by a part-time driver on staff with a truck owned by the hub. Delivery frequency varied from every day to once a week depending on season and produce availability.

Hub C, a nonprofit located in the North Carolina mountains outside Asheville, was established in 2012. It has sought to increase farm income and maintain farmland by providing a means for small and midscale growers to access markets. The average farm size in the area is 75 acres (30 hectares). A number of farms experienced 
significant decline over the last decade due to declines in tobacco income; the current major agricultural activities are livestock, dairy, and some row crop farming (USDA NASS, 2014). Hub C received initial funding from the county economic development office supplemented with grant and foundation funding. The hub sought to help farmers who had previously grown tobacco to maintain their land as working farms by replacing tobacco with vegetable and fruit crops and individuals interested in farming as a part-time occupation. Unlike Hubs A and B, Hub C was a membershipbased organization with a modest annual fee and required growers to sign a non-compete contract that disallowed growers from selling directly to hub customers for one year. Hub $\mathrm{C}$ aggregated most produce from within a 40 -mile $(64-\mathrm{km})$ radius. In 2014 , about $20 \%$ of its product was sold direct to grocery stores and $80 \%$ was delivered to a regional grocery distribution center located 100 miles (160 $\mathrm{km}$ ) from the hub. Farmers could bring unboxed product to the hub for grading and packing, or could bring product already packed in boxes. Deliveries were done approximately 4 days per week on a truck owned by the county, which also paid the salary of the driver.

Hub D began as a nonprofit cooperative of organic growers in the early 2000s and was initially financed through the Tobacco Trust Fund ${ }^{3}$. The area's average farm size is 96 acres (39 hectares), and significant agricultural activity is in Christmas tree, cattle, and tobacco production, as well as some produce (USDA, 2012). Hub D did not operate fully or profitably for many years, and in 2014 changed its legal status to a limited liability corporation (LLC) with sole ownership. Most of the products sold by this hub are specialty crops grown using organic practices by very small operations (median size less than 2 acres [1 hectare]), although not all the products are organically certified. Approximately $75 \%$ of the hub's products are delivered directly to restaurants, $15 \%$ directly to grocery stores, and 10\% to a wholesale distributor.

\footnotetext{
${ }^{3}$ The Tobacco Trust Fund supports programs that encourage a strong agricultural industry in North Carolina by striving to make a positive impact on current and former tobacco growers.
}

Farmers bring in product already packed and ready to be divided into orders for delivery. Part of Hub D's cooling and delivery equipment is owned and part is leased. Produce is delivered 4 times per week by a staff driver.

\section{Analysis}

Detailed financial records for 2014 were collected from three food hubs (Hubs A, B, and C) and a summary of expenses and revenues was obtained from Hub D. All expenses were categorized by type, including product purchased from farmers, delivery-related expenses, salaries and wages, administrative expenses (rent, utilities, office supplies, technology, travel, accounting services, liability insurance, workers' compensation, etc.), and other expenses (packaging, repairs, maintenance, etc.). Revenues were also categorized as food sales, delivery charges, and monetary donations. In-kind donations such as volunteer time were not considered. Annual net revenues were calculated as total annual revenues including monetary donations less total annual operating expenses. Financial viability was indicated by positive net annual revenues.

Average mark-up, a percent difference between the price received from a buyer and the price paid to a farmer, was estimated by food hub managers because actual figures varied from one transaction to another. A distinguishing factor of food hubs is that they operate with transparent margins: the hub charges growers a fixed percentage for its services based on the value of the product that is sold. A margin of $20 \%$ has been typical for North Carolina food hubs, with the hubs retaining $20 \%$ of the sale value of the product to pay for operations and the remaining $80 \%$ paid to the growers. This percentage can differ slightly from transaction to transaction based on additional services a hub provides, such as grading and packing.

During our visits we discussed with food hub managers their expectations of operational expenses and revenues associated with an economically viable food hub business. Managers of all hubs, with the exception of Hub D, were well aware that their hubs were not operating with sufficient revenues to cover operating expenses. 
They attributed this to inadequate infrastructure and staff necessary to move a greater volume of product. For that reason, in the interviews we gathered data on additional throughput that managers believed would be required for economic viability and the additional operating expenses needed to support a larger scale of operation. We concentrated on required essential personnel and compensation, space, and delivery schedule. The hubs managers all had similar perceptions on the minimum level of these inputs required for economic viability, e.g., two staff members responsible for running hub operations, a 3-times-per-week delivery schedule, etc. Based on both the actual operating expenses and revenues and expected additional costs incurred with higher throughput levels, we developed a model annual operational budget for a food hub with assumed mark-ups and estimated revenues required for economic viability. In the development of the budget we assumed that no revenues would come from grants and subsidies to support food aggregation and distribution activities.

We also assumed that adequate infrastructure, transportation, and cooling and storage equipment were available and owned by the food hub. Food hubs, including the four hubs we visited, differ significantly in terms of available infrastructure and equipment and their ownership and management. Therefore we did not take any expenses related to infrastructure ownership into account as they can vary greatly depending each hub's specific circumstances. We assumed a mark-up of $20 \%$, which was consistent with the average values reported by the food hubs we visited.

In the construction of the food hub model annual operating budget, we assumed that deliveries would average 8 hours per day, 3 times per week, resulting in 1,248 estimated annual delivery hours. Only operating costs were considered for delivery; no ownership-related expenses were included for the delivery transport. Fuel costs were estimated at $\$ 2.50$ per gallon ( $\$ 0.66$ per L), 12 miles per gallon (19.6 liters $/ 100 \mathrm{~km}$ ) average fuel consumption, and 50 miles per hour (80 km per hour) average speed. Delivery transport insurance was assumed to be $\$ 1,000$ per year and maintenance $\$ 833$ per year.
Based on current labor use and projections for greater throughput, we assumed that at least $\$ 100,000$ would be required annually in salaries and wages. Specific circumstances may vary, but to support the operations of a food hub at least two people (full or part-time) would be required. Labor costs in our model also included a driver contracted on an hourly basis at $\$ 15$ per hour for 1,248 hours of delivery time $(\$ 18,720$ per year); a food hub manager to make sales calls; and another staff person to manage warehouse inventory, farmer deliveries, packing, etc. (both combined at $\$ 70,000$ per year); and the remainder (about $\$ 10,000$ per year) would be spent on part-time help. The various administrative expenses included rent, utilities, office supplies, computer software, accounting services, liability insurance, promotional and advertising expenses, and maintenance.

We based our calculations for the annual revenues required to support operations on estimated annual operational costs and mark-up level. It was assumed that the revenue was received from food sales exclusively. We conducted sensitivity analysis of required revenue from food sales with respect to different mark-up levels and total expected annual expenses (based on different throughput levels) in order to establish how sensitive our results were to selected values.

\section{Results}

Table 1 summarizes the annual operational expenses and revenue information collected from three of the hubs we visited (Hub A, B, and C). Next we describe the actual revenues and expenses collected per hub and present a composite model budget we developed to estimate minimally required operational expenses for a food hub business. We conclude this section with the results of sensitivity analysis of revenues required to cover operating expenses, with respect to different levels of annual operational expenses and mark-ups.

\section{Hub $A$ Expenses and Revenues}

Hub A's annual revenues have been growing continuously based on the organization's financial records and reached $\$ 227,689$ in 2014. Ninetythree percent of Hub A's revenues $(\$ 212,210)$ came from food sales, $2 \%(\$ 5,119)$ from delivery charges 
(buyers paid $\$ 5$ for each delivery under $\$ 300$ ), and $5 \%$ from monetary donations to the program. Over the course of the year, Hub A paid $\$ 161,102$ to farmers for their products, resulting in an average mark-up for the hub of $24 \%$. Excluding food purchases from the farmers, total annual operating expenses were estimated at $\$ 133,552$. This included $\$ 18,245$ to deliver produce once per week throughout the year by a hired truck and driver. Approximately $\$ 90,000$ was paid in salaries and wages to warehouse staff managing distribution operations, including one full-time staff person at $\$ 40,000$ per year and several part-time workers who were paid hourly rates. Administrative expenses of the distribution program were estimated at $\$ 20,996$, with subsidized rent for warehouse space. Net revenue was calculated as total revenue less total expenses and was estimated to be negative $\$ 66,965$ in 2014 . If we also exclude monetary donations, net revenue would be negative $\$ 77,325$, which is an underestimate of losses as this does not include the rent subsidized by local government and the volunteer labor received. If we assume that all revenues come from food sales and the average mark-up remains at $24 \%$, the total revenue would need to be $\$ 556,467$ for the hub's distribution operations to be sufficient to cover an assumed $\$ 133,522$ level of annual operational expenses.

\section{Hub B Expenses and Revenues}

Hub B's total revenues were $\$ 167,959$ in 2014 , out of which $83 \%$ ( $\$ 139,909)$ was produce sales, $15 \%$ $(\$ 24,981)$ was grants, and $\%(\$ 3,069)$ was revenue from packaging sales. Hub B paid $\$ 117,340$ to growers for produce they supplied. The average mark-up reported by staff was $20 \%$. Total operational expenses of the hub, excluding food purchases from growers, were $\$ 109,964$. The hub owned a refrigerated truck and a van, both purchased using grant funds from previous years. The total delivery expenses were estimated at $\$ 8,694$. Hub staff included a full-time facility manager, a driver, and part-time labor supporting facility operations, including the washing, grading, and packing line. Total payroll expenses were $\$ 59,986$. Total administrative expenses were $\$ 19,270$, which included utilities, office supplies, workers' com- pensation and liability insurance, computer support, accounting, advertising, and other expenses. Facility rent was subsidized. Other operationrelated expenses totaled $\$ 22,014$. Hub B net revenue was negative $\$ 59,345$, and negative $\$ 84,326$ if monetary donations are excluded as a source of revenue. Assuming that all revenues are coming from food sales and with an average markup at $20 \%$, total revenue from produce sales would have to be $\$ 549,820$ to cover an estimated $\$ 109,964$ in annual operational expenses (exclusive of produce purchased from growers).

\section{Hub C Expenses and Revenues}

In 2014, Hub C total revenues were $\$ 265,494$, including 51\% (\$135,886) in produce sales, $41 \%$ $(\$ 109,940)$ in various monetary donation and grants, $6 \%(\$ 17,428)$ in packaging sales, and $2 \%$ $(\$ 2,240)$ in revenues from membership dues and advertising sales. The above mentioned monetary donations included funds provided by the county to cover some of the hub's operational expenses, such as rent, utilities, driver salary, warehouse improvements, etc. Total operational expenses excluding produce purchases from growers were $\$ 143,286$ in 2014, including fuel and maintenance for the delivery truck, rent, utilities, and other expenses. A reported $\$ 16,012$ was spent on various warehouse improvements and would not be representative of a typical year. Net revenue in 2014 was $\$ 12,980$ when the $\$ 109,940$ from public funding is included; it was negative $\$ 96,960$ if monetary public support was excluded. Based on the current $20 \%$ mark-up fee to growers and revenues and excluding public or foundational funds, the facility would need $\$ 716,430$ in annual sales to cover the estimated $\$ 143,286$ in annual operational expenses (excluding the purchase cost of produce).

\section{Hub D Expenses and Revenues}

Detailed accounting records were not available from this hub, and so it was not included in Table 1. Hub D sales reached an estimated $\$ 600,000$ in 2014 and the total operational expenses were approximately $\$ 150,000$, with an average mark-up 
Table 1. Annual Revenues and Expenses of Three Food Hub Businesses, 2014

\begin{tabular}{|c|c|c|c|}
\hline Revenue or Expense Category & Hub A & Hub B & Hub C \\
\hline \multicolumn{4}{|l|}{ Revenues } \\
\hline Produce Sales & $\$ 212,210$ & $\$ 139,909$ & $\$ 135,886$ \\
\hline Delivery Charges & 5,119 & & \\
\hline Monetary Donations and Grants & 10,360 & 24,981 & 109,940 \\
\hline Packaging Sales & & 3,028 & 17,428 \\
\hline Advertising Sales & & & 1,500 \\
\hline Membership Dues & & & 680 \\
\hline Other Revenue & & 41 & 60 \\
\hline Total Revenues & $\$ 227,689$ & $\$ 167,959$ & $\$ 265,494$ \\
\hline Produce Purchased from Farmers (\$/year) & $\$ 161,102$ & $\$ 117,340$ & $\$ 109,228$ \\
\hline \multicolumn{4}{|l|}{ Operational Expenses } \\
\hline \multicolumn{4}{|l|}{ Delivery Expenses } \\
\hline Hired Truck & $\$ 18,245$ & & \\
\hline Unloading Fees & & $\$ 4,560$ & \\
\hline Fuel & & 3,306 & $\$ 2,490$ \\
\hline Truck Insurance & & 624 & \\
\hline Truck Maintenance & & 204 & 259 \\
\hline Total Delivery Expenses & $\$ 18,245$ & $\$ 8,694$ & $\$ 2,749$ \\
\hline Salaries and Wages (Warehouse Staff, Driver, Part-Time Labor) & $\$ 90,000$ & $\$ 59,986$ & $\$ 41,210$ \\
\hline \multicolumn{4}{|l|}{ Administrative Expenses } \\
\hline Rent & $\$ 4,000$ & & $\$ 30,000$ \\
\hline Utilities & 3,309 & $\$ 13,619$ & 5,866 \\
\hline Office and Warehouse Supplies & 1,066 & 1,068 & 3,287 \\
\hline Computer Software and Upgrades & 516 & 492 & 1,167 \\
\hline Conferences, Meetings, Training, Subscriptions, Permits & 1,041 & 463 & 698 \\
\hline Travel & 1,445 & 329 & 651 \\
\hline Accounting Services & 4,594 & & 12,344 \\
\hline Liability Insurance & 1,025 & 1,169 & 1,827 \\
\hline Workers' Compensation & & 2,000 & \\
\hline Advertising & 4,000 & 130 & 1,186 \\
\hline Total Administrative Expenses & $\$ 20,996$ & $\$ 19,270$ & $\$ 57,026$ \\
\hline \multicolumn{4}{|l|}{ Other Expenses } \\
\hline Equipment Purchases & $\$ 1,355$ & $\$ 2,650$ & $\$ 2,041$ \\
\hline Building Renovations and Landscaping & & & 16,012 \\
\hline Equipment Rental & & 913 & \\
\hline Donations, Events, and Charitable Contributions & 1,741 & & 1,620 \\
\hline Packaging & & 6,000 & 17,184 \\
\hline Repairs and Maintenance & & 1,461 & 4,397 \\
\hline Miscellaneous & 1,025 & 10,990 & 1,047 \\
\hline Total Other Expenses & 1,741 & 22,014 & 42,301 \\
\hline Total Operational Expenses (Excluding Produce Purchased) & $\$ 133,552$ & $\$ 109,964$ & $\$ 143,286$ \\
\hline Net Revenue & $(\$ 66,965)$ & $(\$ 59,345)$ & $\$ 12,980$ \\
\hline Net Revenue Less Monetary Donations & $(\$ 77,325)$ & $(\$ 84,326)$ & $(\$ 96,960)$ \\
\hline Reported Average Markup & $24 \%$ & $20 \%$ & $20 \%$ \\
\hline Total Revenue from Produce Sales Needed to Cover Operating Costs & $\$ 556,467$ & $\$ 549,820$ & $\$ 716,430$ \\
\hline
\end{tabular}

Note: All amounts are in US\$. 
of slightly over $20 \%$. Hub D owned a refrigerated delivery truck and leased a delivery van. Deliveries were done 4 times per week, each lasting approximately 12 hours. In winter, the number of delivery days was reduced to three. Hub D paid $\$ 7,800$ in annual rent. It had workers' compensation and liability insurance $(\$ 2,500$ per year) with two full-time and one part-time office staffers and a driver who was paid hourly.

\section{Model Food Hub Annual Operating Budget}

Table 2 presents the model budget developed for a generic food hub business with revenues sufficient to cover operating costs. Total annual delivery expenses were estimated at slightly under $\$ 15,000$, including $\$ 13,000$ for fuel, $\$ 1,000$ for insurance, and $\$ 833$ for maintenance. This estimate did not include any ownership-related expenses, such as taxes, leasing fees, or depreciation, as these vary greatly depending on specific circumstances. Total salaries and wages were estimated at $\$ 100,000$ per year, including two warehouse staffers, a part-time driver, and parttime warehouse help. Total annual administrative expenses were estimated at $\$ 44,000$, resulting in a total estimate of operational expenses of $\$ 158,833$. Assuming a $20 \%$ average mark-up, annual food sales required to support this level of operational expenses would need to be approximately $\$ 800,000$.

\section{Sensitivity Analysis}

Since the data presented in Table 2 were only estimates and actual figures vary from one food hub business to another and from one year to another, Table 3 presents required total revenues at different levels of average mark-up (10\% to $40 \%$ ) and different levels of annual operating expenses.
Table 2. Estimated Minimally Required Annual Operational Budget for a Food Hub Business

\begin{tabular}{lr}
\hline Revenue/Expense Category & $\begin{array}{r}\text { Amount } \\
(\$ / \text { year) }\end{array}$ \\
\hline Operational Expenses & \\
Delivery Expenses & \\
$\quad$ Fuel & $\$ 13,000$ \\
$\quad$ Truck Insurance & 1,000 \\
$\quad$ Truck Maintenance & 833 \\
Total Delivery Expenses & $\$ 14,833$ \\
Salaries and Wages (Warehouse Staff, Driver, Part-Time Labor) & $\$ 100,000$ \\
Administrative Expenses & \\
$\quad$ Rent & \\
$\quad$ Utilities & $\$ 12,000$ \\
$\quad$ Office Supplies & 10,000 \\
Computer Software and Upgrades & 1,000 \\
Accounting Services & 5,000 \\
$\quad$ Liability Insurance & 5,000 \\
$\quad$ Advertising, Promotions, Events & 1,000 \\
$\quad$ Repairs and Maintenance & 5,000 \\
Total Administrative Expenses & 5,000 \\
Total Operational Expenses (Excluding Produce Purchased) & $\$ 44,000$ \\
Reported Average Markup & $\$ 158,833$ \\
Total Revenue from Produce Sales Needed to Cover Operating Costs & $\$ 794,165$ \\
\hline
\end{tabular}

These expenses represent $20 \%$ and $10 \%$ reductions, and $20 \%, 40 \%, 60 \%, 80 \%$, and $100 \%$ increases relative to the originally estimated value (\$158,833 per year). The higher the mark-up, the lower the level of required annual sales to cover a particular level of annual operational expenses. The higher the annual operating expenses, the higher the required annual sales to cover these expenses at each average mark-up level. Estimated levels of required annual sales varies from $\$ 317,666$ at a $\$ 127,066$ level of annual expenses and $40 \%$ markup, to $\$ 3,176,660$ at a $\$ 317,660$ level of annual expenses and $10 \%$ mark-up.

\section{Summary and Conclusions}

The four food hubs represented in this study varied with respect to their business models, ownership structures, market channels, etc., and had been in operation from two to more than 10 years. All started out with public funding, and the 
Table 3. Sensitivity Analysis of Minimally Required Revenue from Produce Sales with Respect to Various Levels of Annual Operational Expenses and Average Markup

\begin{tabular}{|c|c|c|c|c|c|c|c|c|}
\hline \multirow{2}{*}{$\begin{array}{l}\text { Annual } \\
\text { Operational } \\
\text { Expenses } \\
\text { (\$/year) }\end{array}$} & \multirow{2}{*}{$\begin{array}{c}\text { Annual } \\
\text { Operational } \\
\text { Expenses Relative } \\
\text { to Originally } \\
\text { Estimated Value } \\
(\$ 158,833)\end{array}$} & \multicolumn{7}{|c|}{ Revenue at Average Markup } \\
\hline & & $10 \%$ & $15 \%$ & $20 \%$ & $25 \%$ & $30 \%$ & $35 \%$ & $40 \%$ \\
\hline$\$ 127,066$ & $-20 \%$ & $1,270,664$ & 847,109 & 635,332 & 508,266 & 423,555 & 363,047 & 317,666 \\
\hline$\$ 142,950$ & $-10 \%$ & $1,429,497$ & 952,998 & 714,749 & 571,799 & 476,499 & 408,428 & 357,374 \\
\hline$\$ 158,833$ & - & $1,588,330$ & $1,058,887$ & 794,165 & 635,332 & 529,443 & 453,809 & 397,083 \\
\hline$\$ 190,600$ & $+20 \%$ & $1,905,996$ & $1,270,664$ & 952,998 & 762,398 & 635,332 & 544,570 & 476,499 \\
\hline$\$ 222,366$ & $+40 \%$ & $2,223,662$ & $1,482,441$ & $1,111,831$ & 889,465 & 741,221 & 635,332 & 555,916 \\
\hline$\$ 254,133$ & $+60 \%$ & $2,541,328$ & $1,694,219$ & $1,270,664$ & $1,016,531$ & 847,109 & 726,094 & 635,332 \\
\hline$\$ 285,899$ & $+80 \%$ & $2,858,994$ & $1,905,996$ & $1,429,497$ & $1,143,598$ & 952,998 & 816,855 & 714,749 \\
\hline$\$ 317,666$ & $+100 \%$ & $3,176,660$ & $2,117,773$ & $1,588,330$ & $1,270,664$ & $1,058,887$ & 907,617 & 794,165 \\
\hline
\end{tabular}

hubs upon which detailed analysis was based for this paper continue to receive significant subsidization. Net revenues in 2014 excluding donations and grants averaged negative $\$ 86,204$ across the three hubs analyzed.

A model budget indicates that total revenues from wholesale produce sales alone necessary to operate a food hub without public funding is nearly $\$ 800,000$ annually. This assumes the hub charges growers a $20 \%$ mark-up fee on products handled by the hub. This fee then covers the approximate $\$ 160,000$ in operational expenses (excluding the cost of produce). These numbers represent only the selected operational expenses and do not include the cost of infrastructure investment and ownership (i.e., taxes, financing costs, or depreciation). Ownership costs should be factored in for the assessment of each particular operation as they affect the estimated sale amounts required for viability. For example, Matson and Barham's (2015) estimated value of required breakeven sales that considered ownership-related costs was around $\$ 1.2$ million. Sensitivity results presented in Table 3 could be used as a guide to inform readers about the possible level of sales required to cover higher levels of costs.

As noted, the typical service-fee mark-up level across the focal hubs and assumed for the model budget in Table 2 was $20 \%$. Considering the losses and related public subsidization required at this level, communities considering investment in a food hub should balance the expected benefits of subsidization against alternative uses of these funds. Charging a higher fee to growers is one way to reduce subsidization. Fischer's analysis of the 2013 USDA food hub survey found that the median mark-up for financially viable food hubs was 39\% (Fischer, 2014, p. 88). A promising area of future research is investigation of the impact of higher food hub mark-up fees on food hub viability as well as on the existing and potential economic impact of these fees on the small-scale growers and agricultural communities served by hubs. Communities considering investing in a food hub should also carefully consider the market channels available to the hub and prices associated with each: Matson and Barham (2015) note that food hubs selling direct-to-consumer, at presumably higher unit prices, can be economically viable at a lower level of gross revenue than those selling to intermediated entities such as groceries and institutions. But rural areas may not have the consumer base required to support a direct-toconsumer hub model.

The share of salaries and wages in the model operational budget is $12.5 \%$ of required annual revenues. In reality, food hubs similar to those we visited that have low annual sales find it difficult to 
keep salary-related expenses under $15 \%$ of revenues and at the same time employ adequate staff. Insufficient staff is a major barrier to growth, which is compounded by an inability to hire more staff because of low sales (Fischer, 2014). Food hubs, which as nonprofits often have limited access to borrowed funds, rely on external funding to maintain adequate staff as well as to provide various services beyond food aggregation and distribution for which they do not charge fees.

Because of the potential social and economic benefits that can accrue from an active local food system, rural communities seeking to revitalize local agriculture and affiliated businesses often consider and subsequently make investments in food hub infrastructure. Despite the assumed social mission and public good attributes of food hubs, however, these facilities are often expected to operate as economically self-sustaining businesses within a fairly short amount of time. Grant proposals typically assume that initial public funding will provide the "start-up capital," and the hub is anticipated to become independent of public funding in 3 to 5 years. As indicated both by the findings of this paper, based on detailed results of hubs operating in North Carolina in 2014, and the 2013 financial benchmarking study of hubs (Farm Credit East, Wallace Center at Winrock International, Morse Marketing Connections, \& Farm Credit Council, 2015), this is very often not the case: infusions of public funds are necessary for the hub to continue operations. Food hub infrastructure can provide a valuable tool for economic development, and realistic assessments of the public or foundation funding needed for their successful operation should be considered from inception.

\section{References}

Atallah, S. S., Gómez, M. I., \& Björkman, T. (2014). Localization effects for a fresh vegetable product supply chain: Broccoli in the eastern United States. Food Policy, 49(1), 151-159. http://dx.doi.org/10.1016/j.foodpol.2014.07.005

Barham, J., Tropp, D., Enterline, K., Farbman, J., Fisk, J., \& Kiraly, S. (2012). Regional food hub resource guide. Washington, D.C.: USDA AMS. Retrieved from http://dx.doi.org/10.9752/MS046.04-2012
Blay-Palmer, A., Landman, K., Knezevic, I., \& Hayhurst, R. (2013). Constructing resilient, transformative communities through sustainable "food hubs." Local Environment: The International Journal of Justice and Sustainability, 18(5), 521-528. http://dx.doi.org/10.1080/13549839.2013.797156

Cantrell, P., \& Heuer, B. (2014, March 4). Food bubs: Solving local [Press release]. The Wallace Center at Winrock International. Retrieved from: http://ngfn.org/solvinglocal

Cleveland, D. A., Müller, N. M., Tranovich, A. C., Mazaroli, D. N., \& Hinson, K. (2014). Local food hubs for alternative food systems: A case study from Santa Barbara County, California. Journal of Rural Studies, 35, 26-36. http://dx.doi.org/10.1016/j.jrurstud.2014.03.008

Connelly, S., Markey, S., \& Roseland, M. (2011). Bridging sustainability and the social economy: Achieving community transformation through local food initiatives. Critical Social Policy, 31(2), 308-324. http://dx.doi.org/10.1177/0261018310396040

Day-Farnsworth, L., \& Morales, A. (2011). Satiating the demand: Planning for alternative models of regional food distribution. Journal of Agriculture, Food Systems and Community Development, 2(1), 227-248. http://dx.doi.org/10.5304/jafscd.2011.021.020

Dion L., Shugart, D., Hale, J., \& Saavedra, J. (2013). Galesburg food bub feasibility study. Galesburg Regional Economic Development Association. Retrieved from http:// foodsystems.msu.edu/uploads/ files/Galesburg Feasibility Study.pdf

Dunning, R, Bloom, J. D., \& Creamer, N. (2015). The local food movement, public-private partnerships, and food system resiliency. Journal of Environmental Studies and Sciences, 5(4), 661-670. http://dx.doi.org/10.1007/s13412-015-0295-z

Farm Credit East, Wallace Center at Winrock International, Morse Marketing Connections, \& Farm Credit Council. (2015). Counting V alues: Food bub financial benchmarking study. Retrieved from: http://www.ngfn.org/resources/ngfndatabase/knowledge/Food $\% 20 \mathrm{Hub} \% 20$ Benchmar king $\% 20$ Study.pdf

Fischer, M. (2014). Investigation and analysis of food bub operations (Master's thesis). Michigan State University, Ann Arbor, Michigan. Retrieved from ProQuest (Publication no. 1554359). 
Fischer, M., Hamm, M., Pirog, R., Fisk, J. Farbman, J., \& Kiraly, S. (2013). Findings of the 2013 national food bub survey. Michigan State University Center for Regional Food Systems and the Wallace Center at Winrock International. Retrieved from http:/ / foodsystems.msu.edu/resources/2013-foodhub-survey

Fischer, M., Pirog, R., \& Hamm, M. W. (2015). Predictors of food hub financial viability. Journal of Hunger and Environmental Nutrition, 10(1), 100-114. http://dx.doi.org/10.1080/19320248.2014.962774

Gillespie, G., Hilchey, D. L., Hinrichs, C. C., \& Feenstra, G. (2007). Farmers' markets as keystones in rebuilding local and regional food systems. In C. C. Hinrichs \& T. A. Lyson (Eds.), Remaking the North American food system: Strategies for sustainability (pp. 65-83). Lincoln: University of Nebraska Press.

Gunter, A., Thilmany, D., \& Sullins, M. (2012). What is the new version of scale efficient: A values-based supply chain approach? Journal of the Food Distribution Research Society, 43(1), 27-34. http://purl.umn.edu/139447

Hinrichs, C. C., Gillespie, G. W., \& Feenstra, G. W. (2004). Social learning and innovation at retail farmers' markets. Rural Sociology, 69(1), 31-58. http://onlinelibrary.wiley.com/journal/10.1111/ (ISSN)1549-0831

Hodbod, J., \& Eakin, H. (2015). Adapting a socialecological resilience framework for food systems. Journal of Environmental Studies and Science, 5(3), 474484. http://dx.doi.org/10.1007/s13412-015-0280-6

Horst, M., Ringstrom, E., Tyman, S., Ward, M. K., Werner, V., \& Born, B. (2011). Toward a more expansive understanding of food hubs. Journal of Agriculture, Food Systems, and Community Development, 2(1), 209-225. http://dx.doi.org/10.5304/jafscd.2011.021.017

Jablonski, B. B. R., Perez-Burgos, J., \& Gómez, M. I. (2011). Food value chain development in central New York: CNY Bounty. Journal of Agriculture, Food Systems, and Community Development, 1(4), 129-141. http://dx.doi.org/10.5304/jafscd.2011.014.015

Jablonski, B. B. R., Schmit, T. M., \& Kay, D. (2015). Assessing the economic impacts of food hubs to regional economies: A framework including opportunity cost (Working Paper No. 2015-03). Charles H. Dyson School of Applied Economics and Management,
College of Agriculture and Life Sciences, Cornell University. Retrieved from http://dyson.cornell.edu/research/working-papers

King, R. P., Hand, M. S., DiGiacomo, G., Clancy, K., Gómez, M. I., Hardesty, S. D.,...McLaughlin, E. W. (2010). Comparing the structure, size, and performance of local and mainstream food supply chains (Economic Research Service Report No. km ERR-99). Retrieved from http://www.ers.usda.gov/ publications/err-economic-researchreport/err99.aspx

LeBlanc, J. R., Conner, D., McRae, G., \& Darby, H. (2014). Building resilience in nonprofit food hubs. Journal of Agriculture, Food Systems, and Community Development, 4(3), 121-135. http://dx.doi.org/10.5304/jafscd.2014.043.005

Lindsey, T. C., \& Slama, J. (2012). Building successful food bubs: A business planning guide for aggregating and processing local food in Illinois. Illinois Department of Commerce and Economic Opportunity, University of Illinois Business Innovation Services, and Illinois Department of Agriculture. Retrieved from http://www.familyfarmed.org/publications/ building-successful-food-hubs/

Low, S. A., Adalja, A., Beaulieu, E., Key, N., Martinez, S., Melton, A.,...Jablonski, B. B. R. (2015). Trends in U.S. local and regional food systems: $A$ report to Congress (Administrative Publication No. AP-068). Washington, D.C.: USDA, Economic Research Service. Retrieved from http:/ / www.ers.usda.gov/ publications/ap-administrative-publication/ap068.aspx

Low, S. A., \& Vogel, S. J. (2011). Direct and intermediated marketing of local foods in the United States (Publication No. ERR-128). Washington, D.C.: USDA, Economic Research Service. http://dx.doi.org/10.2139/ssrn.2114361

Lutz, J., \& Schachinger, J. (2013). Do local food networks foster socio-ecological transitions towards food sovereignty? Learning from real place experiences. Sustainability, 5(11), 4778-4796. http://dx.doi.org/10.3390/su5114778

Marticorena, D. C. W. (2015). Statistical analysis of diverse issues in sustainable agriculture. (Doctoral dissertation). North Carolina State University. Retrieved from https://repository.lib.ncsu.edu/ir/bitstream/1840.1 6/10520/1/etd.pdf 
Martinez, S., Hand, M. S., Da Pra, M., Pollack, S., Ralston, K., Smith, T.,...Newman, C. (2010). Local food systems: Concepts, impacts, and issues (Publication No. ERR 97). Washington, D.C.: USDA ERS. Retrieved from http://www.ers.usda.gov/publica tions/err-economic-research-report/err97.aspx

Matson, J., \& Barham, J. (2015). The million dollar question: What is break-even and viability for different food hub models? [Webinar]. National Good Food Network, Wallace Center at Winrock International. Retrieved from http://ngfn.org/resources/ngfn-clustercalls/food-hub-viability

Matson, J., Thayer, J., \& Shaw, J. (2015). Running a food bub: A business operations guide (Vol. 2; Service Report 77). Washington, D.C.: USDA, Rural Development. Retrieved from https://www.rd.usda.gov/files/ SR 77 Running A Food Hub Vol 2.pdf

McFadden, D. T., \& Marshall, M. I. (2014). Local food systems and interactions with entrepreneurship: Editor's introduction. Journal of Food Distribution Research, 45(3), 1-3. http://purl.umn.edu/190651

O’Hara, J. K., \& Pirog, R. (2013). Economic impacts of local food systems: Future research priorities. Journal of Agriculture, Food Systems, and Community Development, 3(4), 35-42. http://dx.doi.org/10.5304/jafscd.2013.034.003

Pothukuchi, K. (2015). Five decades of community food planning in Detroit: City and grassroots, growth and equity. Journal of Planning Education and Research, 35(4), 419-434. http://dx.doi.org/10.1177/0739456X15586630

Purcell, E. A. (2014). An examination of the feasibility of a food hub for the Pee Dee Region (Master's thesis). Clemson University. Retrieved from ProQuest (Publication no. 1558013).

Schmit, T. M., Jablonski, B. B. R., \& Kay, D. (2013). Assessing the economic impact of regional food hubs: The case of Regional Access. Ithaca, New York: Cornell University. http://dx.doi.org/10.9752/MS145.09$\underline{2013}$

Smithson Mills, Inc. (2009). A feasibility analysis and recommendations for development of an agricultural consolidation and marketing center (Prepared for Surry County Government).

Smithson Mills, Inc. (2012). A report on the feasibility of establishing a local foods aggregation, sales and marketing center in Yancey County, North Carolina (Prepared for Yancey County Government). https://yancey.ces.ncsu.edu/files/library/100/ Smithson Final Study draft.doc

U.S. Department of Agriculture [USDA]. (n.d.). Know Your Farmer, Know Your Food. Retrieved July 13, 2016, from http://www.usda.gov/wps/portal/ usda/usdahome?navid=KNOWYOURFARMER

USDA, Agricultural Marketing Service [AMS]. (n.d.-a). National count of farmers market directory listings [Chart]. Retrieved July 13, 2016, from https://www.ams.usda.gov/sites/default/files/ media/FarmersMarketDirectoryListing.jpg

USDA AMS. (n.d.-b). Local food directories: Food bub directory. Retrieved July 13, 2016, from http://www.ams.usda.gov/local-fooddirectories/foodhubs

USDA, National Agricultural Statistics Service [USDA NASS]. (2014). 2012 Census of agriculture: North Carolina state and county data: Volume 1, Geographic Area Series, Part 33. Washington, D.C.: Author. Retrieved from http://www.agcensus.usda.gov/ Publications/2012/Full Report/Volume 1, Chapt er_2_County_Level/North_Carolina/ncv1.pdf

Van Dis, K. (2012). Central Oregon food bub feasibility study. Bend: Central Oregon Intergovernmental Council. Retrieved from http://www.ngfn.org/resources/ ngfn-database/knowledge/central-oregon-foodhub-feasibility-study2.pdf

Wood, P. (2015, October 2). USD A awards \$34.3 million to support communities' local foods infrastructure, increase access to fruits and vegetables funding supports local food systems, farmers markets and healthier eating for SNAP participants [Press release]. Retrieved from http://www.ams.usda.gov/press-release/usdaawards-343-million-support-communities $\% \mathrm{E}$ 2\%80\%99-local-foods-infrastructure-increase 